http://ejournal.undip.ac.id/index.php/kapal

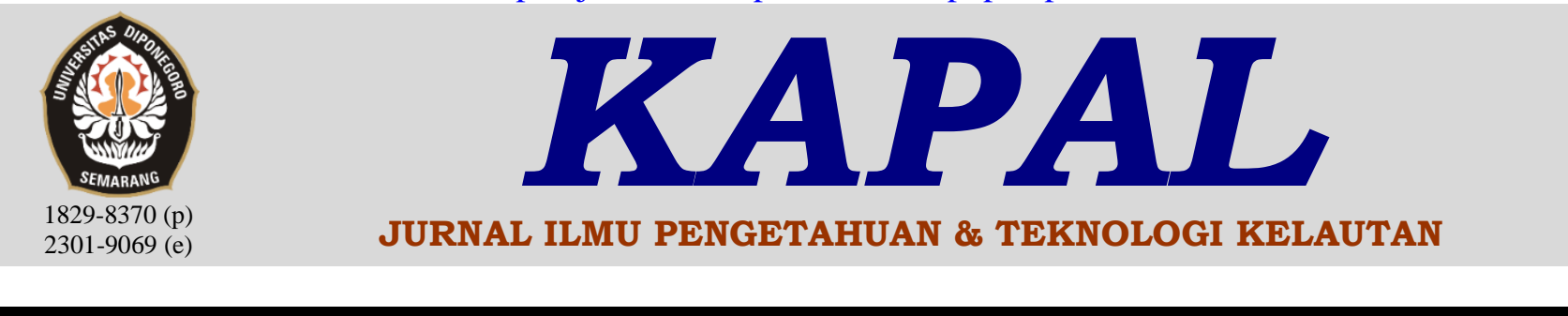

\title{
Pengaruh Variasi Diameter Tool Pin Pada Friction Stir Welding Terhadap Sifat Mekanik Dan Struktur Mikro Sambungan Aluminium 6061-T6
}

\author{
Tarmizi $^{1, *}$, Firman Ode Wijaya ${ }^{2}$, Irfan $^{l}$ \\ ${ }^{1}$ Balai Besar Logam dan Mesin-Kemenperin \\ Jl. Sangkuriang No.12 Bandung, Indonesia 40135 \\ ${ }^{2}$ Jurusan Teknik Metalurgi, Fakultas Teknik, Universitas Jenderal Achmad Yani \\ Jl. Terusan Gatot Subroto, Bandung, Indonesia 40285
}

diajukan pada : 22/05/19

direvisi pada : 28/08/19

diterima pada : 07/10/19

\begin{abstract}
Abstrak
Aluminium merupakan logam yang memiliki sifat mampu las yang kurang baik dibandingkan dengan jenis logam lainnya. Hal tersebut dikarenakan memiliki konduktifitas panas tinggi, koefisien muai besar, dan reaktif dengan udara sehingga mudah terbentuk lapisan oksida $\left(\mathrm{Al}_{2} \mathrm{O}_{3}\right)$ sehingga menghasilkan temperatur cair lebih tinggi dari aluminium murni. Panas yang berlebih pada metode penyambungan GTAW dan GMAW rentan terjadi cacat seperti porositas, crack dan distorsi. Proses Friction Stir Welding (FSW) bisa menjadi solusi untuk mengatasi masalah cacat yang muncul karena proses penyambungan terjadi dibawah temperatur cair logam aluminium. Penelitian ini bertujuan untuk mendapatkan parameter pengelasan yang optimum dengan mengetahui sifat mekanik dan struktur mikro hasil proses FSW pada pelat aluminium 6061- T6. Proses FSW aluminium tipe butt joint tebal 6 mm menggunakan putaran tool konstan $1500 \mathrm{rpm}$, kecepatan pengelasan $29 \mathrm{~mm} / \mathrm{min}$ dengan variasi ukuran berdiameter pin $6 \mathrm{~mm}, 8 \mathrm{~mm} \mathrm{dan} 10 \mathrm{~mm}$. Hasil sambungan spesimen dengan pin berdiameter $6 \mathrm{~mm}$ memiliki sifat mekanik terbaik dengan kuat tarik $144 \mathrm{MPa}$ dan kekerasan 70,27 HVN dibanding spesimen lainnya. Sedangkan pada spesimen dengan pin berdiameter 10 mengalami cacat berupa void (rongga) kecil yang terdapat pada bagian permukaan. Parameter optimum untuk proses FSW aluminium 6061-T6 menggunakan pin dengan diameter 6mm menghasilkan sifat mekanik dan struktir mikro lebih baik daripada penggunaan diameter pin $8 \mathrm{~mm}$ dan $10 \mathrm{~mm}$
\end{abstract}

Copyright $@$ C 2019, KAPAL, 1829-8370 (p), 2301-9069(e)

Kata Kunci : Cacat, Sifat mekanik, Friction Stir Welding , Diameter pin, Aluminium 6061-T6

\section{PENDAHULUAN}

Aluminium dan paduannnya merupakan unsur logam non ferrous yang mempunyai sifat ringan dan memiliki ketahanan korosi yang baik serta penghantar listrik dan panas yang baik. Aluminium memiliki sifat yang mudah dibentuk melalui proses pembentukan maupun proses permesinan[1]. Paduan aluminium ada yang dapat diperlaku-panaskan dan juga paduan yang tidak

*) Penulis Korespondensi :

Email : tarmizi@kemenperin.go.id dapat diperlaku-panaskan. Paduan aluminium magnesium silikon (Al-Mg-Si) termasuk dalam kelompok yang dapat diperlaku-panaskan (heat treable) [2]. Paduan aluminium sangat penting dalam pembuatan komponen dan struktur yang membutuhkan kekuatan tinggi tapi ringan atau kemampuan penghantar listrik yang baik. Diantara semua paduan aluminium, paduan aluminium 6061 dengan elemen paduan utama magnesium dan silikon ( 0,3-1,5\% $\mathrm{Si}, \mathrm{Mg}$ ) mempunyai peran utama dalam industri transportasi seperti perkapalan dan kedirgantaraan [2]-[3]. Paduan 
aluminium banyak digunakan dalam aplikasi tangki penyimpanan bakar ataupun panel-panel pendingin lemari ikan serta platform pendaratan helikopter [4] karena memiliki sifat mampu bentuk yang baik, kemampuan las, kemampuan mesin, tahan korosi, dan kekuatan yang baik dibandingkan dengan paduan aluminium lainnya. Paduan aluminium umumnya diklasifikasikan sebagai paduan yang tidak dapat dilas karena pembekuan struktur mikro yang buruk dan porositas di daerah sambungan. Juga penurunan sifat mekanik hasil las dibandingkan dengan bahan induk. Faktor-faktor ini membuat sambungan aluminium paduan dengan proses pengelasan konvensional tidak menarik. Beberapa aluminium paduan dapat dilas dengan pengelasan konvensional tetapi persiapan permukaannya mahal dan oksida permukaan menjadi masalah utama penyebab munculnya cacat pada sambungan las[5]. Proses pengelasan aluminium paduan masih menjadi tantangan dengan metode pengelasan konvensional. Akan tetapi pengelasan aluminium paduan masih tetap menjadi tantangan menggunakan metode pengelasan konvensional [6].

Untuk mengurangi terjadinya cacat tersebut maka penyambungan aluminium paduan dilakukan dengan metode Friction Stir Welding (FSW) karena pada proses ini tidak menimbulkan panas berlebih yang dapat menyebabkan terbukanya lapisan oksida sehingga hasil kualitas sambungan akan tetap tahan korosi dan tidak terjadi porositas karena tidak ada udara yang terperangkap seperti pada pengelasan GTAW dan GMAW $^{[5]}$. Friction Stir Welding adalah proses penyambungan material dengan kondisi solid state tanpa melelehkan logam induknya dengan memanfaatkan panas dari gesekan antara tool dan logam induk. Metode ini digunakan untuk mengurangi perubahan karakteristik dari logam induk. Friction stir welding merupakan metode penyambungan logam yang masih cukup baru dan dikembangkan pada berbagai parameter yang ada seperti kecepatan putar, kecepatan pengelasan, geometri tool dan arah rotasi tool [5]. Proses pengelasan gesek aduk (FSW) menjadi metode yang paling banyak digunakan dalam pengelasan aluminium paduan [7].

Friction Stir Welding (FSW) merupakan pengelasan tanpa bahan tambah (unconsumable solid-state joining process) dan suhu kerjanya tidak melewati titik lebur benda kerja dan digunakan untuk aplikasi dimana kebutuhan akan perubahan karakteristik dasar dari benda kerja bisa diminimalisir sekecil mungkin. Prinsip kerja proses Friction Stir Welding adalah dengan memanfaatkan gaya gesek dari gesekan antara benda yang berputar (tool) dengan benda yang diam (benda kerja). Tool ini diputar dengan rpm tetap dan melaju dengan kecepatan translasi yang tetap pula sepanjang joining line diantara dua pelat benda kerja yang akan dilas. Gesekan antara tool dan benda kerja tersebut menimbulkan panas hingga $80 \%$ dari titik cair material kerja dan selanjutnya pin ditekan dan ditarik searah daerah yang akan dilas[8]. Selama proses FSW tool dengan putaran tertentu diarahkan pada material sampai shoulder menyentuh permukaan material yg akan disambung. Panas yang muncul akibat gesekan akan melunakkan material di dalamnya dan gerakan translasi akan mendorong material yang ada di depan tool untuk mengisi sisi belakang yang ditinggalkan tool dan akibat gaya aksial akan terbentuk sambungan las[9].

Keuntungan proses FSW adalah tidak ada porositas, tidak ada spatter, penyusutan rendah, hemat energi, tidak ada logam tambah, tidak butuh gas pelindung untuk pengelasan aluminium, distorsi rendah bahkan pada lasan panjang, sifat mekanis lebih baik, tanpa busur, tanpa asap, tidak diperlukan sertifikasi tukang las, tidak perlu gerinda[10].

Menurut R.Ashok Kumar dalam penelitiaannya menjelaskan kualitas sambungan yang terbentuk akan bergantung pada heat input proses FSW seperti putaran tool, kecepatan pengelasan, gaya aksial dan geometri tool. Shoulder merupakan bagian dari tool yang berfungsi sebagai sumber utama pembangkit panas gesekan yang akan melunakkan material secara plastis dan pin akan mengaduk material selama proses berlangsung[11].

Sedangkan penelitian Takhakh menunjukkan bahwa diameter shoulder makin besar sampai pada ukuran diameter tertentu akan meningkatkan sifat mekanik hasil lasan[12]. Proses pengelasan menggunakan FSW tergantung pada parameter pengelasan seperti kecepatan rotasi, kecepatan pengelasan dan gaya aksial yang bekerja selama proses pengelasan.

Penelitian Gharaibeh terkait pengaruh profil pin berbentuk silinder, persegi dan segitiga menunjukkan bahwa bentuk tool juga mempengaruhi struktur mikro dan sifat mekanik daerah pengelasan [13]. Kecepatan putar pahat, kecepatan pengelasan, dan tekanan vertikal pada pelat selama pengelasan adalah parameter proses utama.

Menurut Mohanty dkk geometri tool berkaitan dimensi dan profil juga mempunyai karakteristik penting yang mempengaruhi kekuatan hasil pengelasan [10].

Penelitian mengenai pengaruh diameter pin terhadap kualitas sambungan proses FSW 
dilakukan untuk mendapatkan besarnya masukan panas akibat gesekan tool dengan cara menvariasikan diameter pin yang bergesekan dengan logam induk.

Logam induk aluminium paduan seri $\mathrm{Al}$ 6XXX merupakan jenis aluminium yang dapat di proses perlakuan panas. Selain itu, seri Al 6XXX sangat sensitif terhadap retak panas jika komposisi dari logam pengisi mendekati komposisinya. Aluminium 6061-T6 adalah jenis paduan aluminium-magnesium-silikon. Paduan dalam sistem ini memiliki kekuatan yang lebih kecil dibanding paduan lainnya yang digunakan sebagai bahan tempaan, tetapi sangat liat, sangat baik kemampuan bentuknya untuk penempaan. Aluminium 6061-T6 termasuk dalam kategori heat treatable, yang artinya dapat dilakukan penguatan dengan cara mechanical working dan precipitation hardening[14].

Penelitian ini bertujuan untuk mendapatkan parameter pengelasan yang optimum dengan mengetahui sifat mekanik dan struktur mikro hasil proses Friction Stir Welding aluminium paduan 6061-T6 dengan menvariasikan diameter pin 6, 8, $10 \mathrm{~mm}$.

\section{METODE}

Proses FSW dilakukan di Balai Besar Logam dan Mesin Bandung menggunakan mesin Milling. Logam yang disambung adalah aluminium 6061T6 tebal $6 \mathrm{~mm}$ dengan ukuran $305 \mathrm{~mm} \times 125 \mathrm{~mm}$ dan tipe sambungan butt joint menggunakan tiga variasi diameter pin seperti Gambar 1.

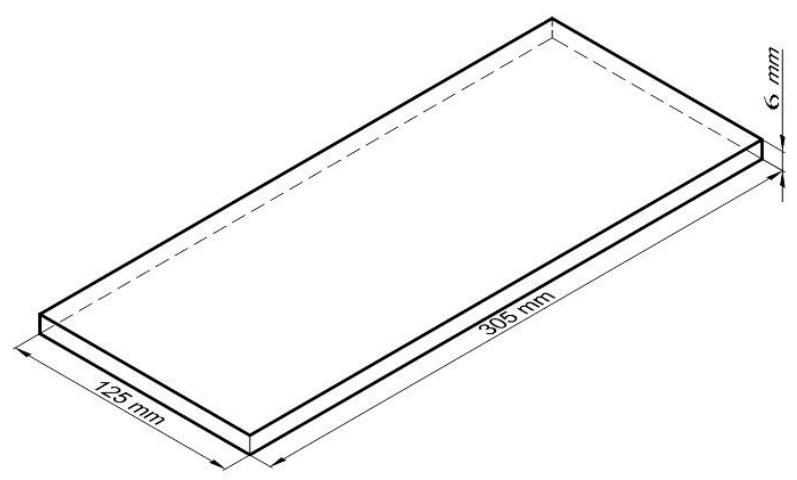

Gambar 1. Skematik Dimensi Material Uji

Proses FSW menggunakan tool yang terbuat dari material tool steel H13berbentuk threaded cylinder dengan diameter shoulder $20 \mathrm{~mm}$ dan panjang shoulder $26 \mathrm{~mm}$. Panjang pin yang digunakan pada penelitian ini 5,6 $\mathrm{mm}$ dan dengan variasi diameter pin $6 \mathrm{~mm}, 8 \mathrm{~mm}, 10 \mathrm{~mm}$ [15]. Bentuk tool yang digunakan pada proses FSW ini seperti ditunjukkan oleh Gambar 2. Parameter proses FSW yang digunakan adalah putaran tool
$1500 \mathrm{rpm}$, kecepatan pengelasan $29 \mathrm{~mm} / \mathrm{min}$ dan sudut kemiringan tool $0^{\circ}$.

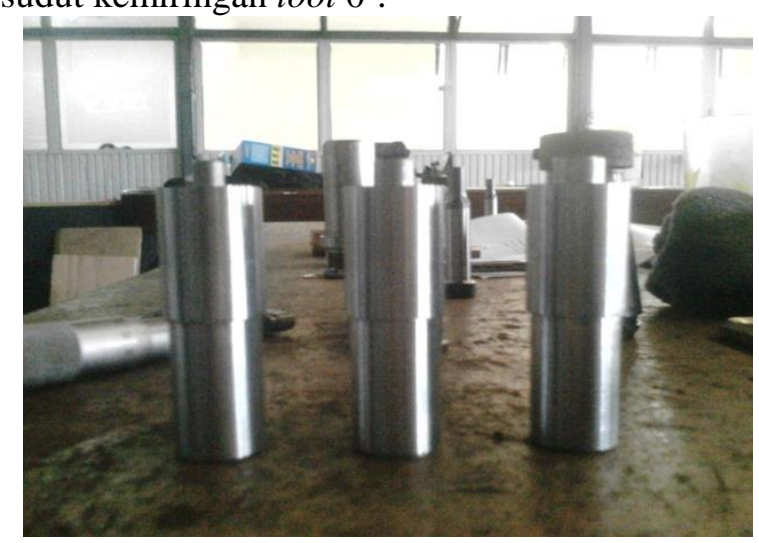

Gambar 2. Bentuk Tool Friction Stir Welding

Tahapan proses yang dilakukan dalam penelitian proses FSW seperti yang ditunjukkan Gambar 3.

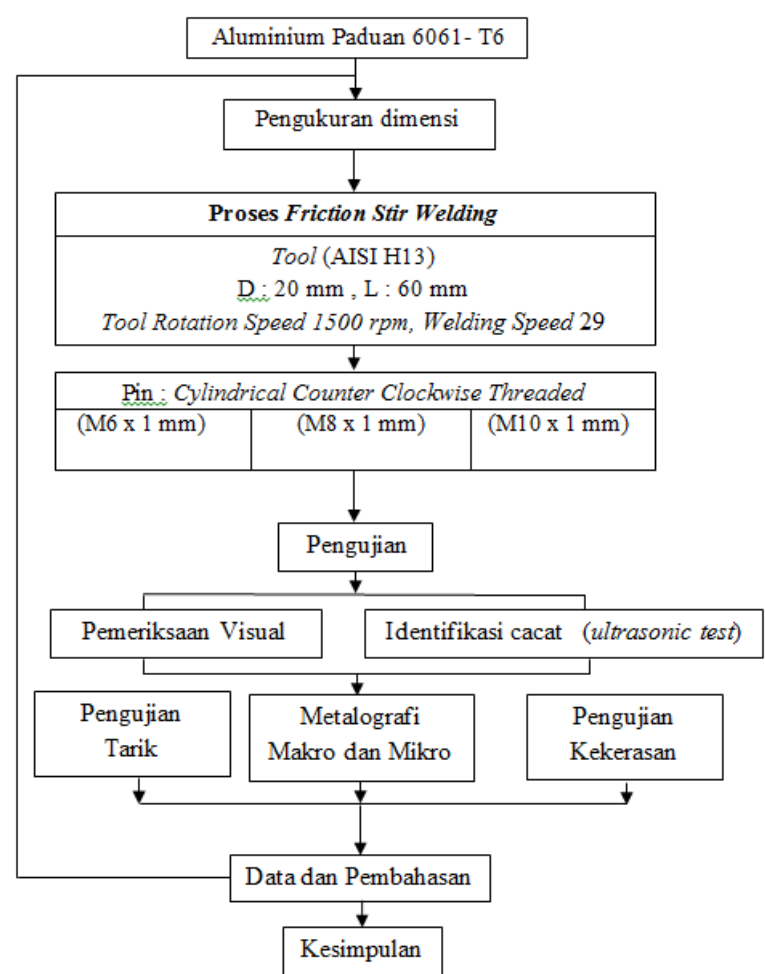

Gambar 3. Diagram alir penelitian FSW aluminium 6061-T6

Proses FSW dilakukan setelah aluminium 6061-T6 sesuai ukuran standar AWS D17.3[16] dicekam atau diklem pada mesin milling. Proses FSW dilakukan sebanyak tiga kali menggunakan diameter pin tool berbeda yaitu $6,8,10 \mathrm{~mm}$. Proses selanjutnya adalah pengujian secara visual dan nondestructive test menggunakan ultrasonik. Pengujian makro dan mikro dilakukan untuk identifikasi cacat dan melihat struktur mikro daerah las. Selanjutnya pengujian tarik dan kekerasan untuk melihat sifat mekanik logam hasil las. 


\section{HASIL DAN PEMBAHASAN}

\subsection{Analisis Visual Hasil Pengelasan}

Pengamatan hasil proses FSW secara visual seperti pada Gambar 4 menunjukkan bahwa penggunaan tool dengan diameter pin $6 \mathrm{~mm}$ menghasilkan flash yang cukup kasar di permukaan atas /face dibandingkan penggunaan diameter pin $8 \mathrm{~mm}$. Sedangkan penggunaan diameter pin $10 \mathrm{~mm}$ terlihat adanya void di permukaan atas/face. Void yang muncul pada spesimen dengan diameter pin $10 \mathrm{~mm}$ akibat kurangnya heat input pada saat proses FSW[17]. Penggunaan pin berdiameter $8 \mathrm{~mm}$ memberikan hasil yang lebih baik dengan flash yang muncul lebih sedikit dan tidak adanya void pada daerah lasan. Flash yang muncul diakibatkan oleh panas berlebih yang melunakkan material uji dan akibat penekanan tool material lunak tersebut terangkat ke atas permukaan menjadi flash[18]. Menurut AWS D17.3[16] bahwa void yang muncul tidak diijinkan sedangkan flash masih bisa diterima dengan syarat harus dibersihkan sebelum pengujian berikutnya.
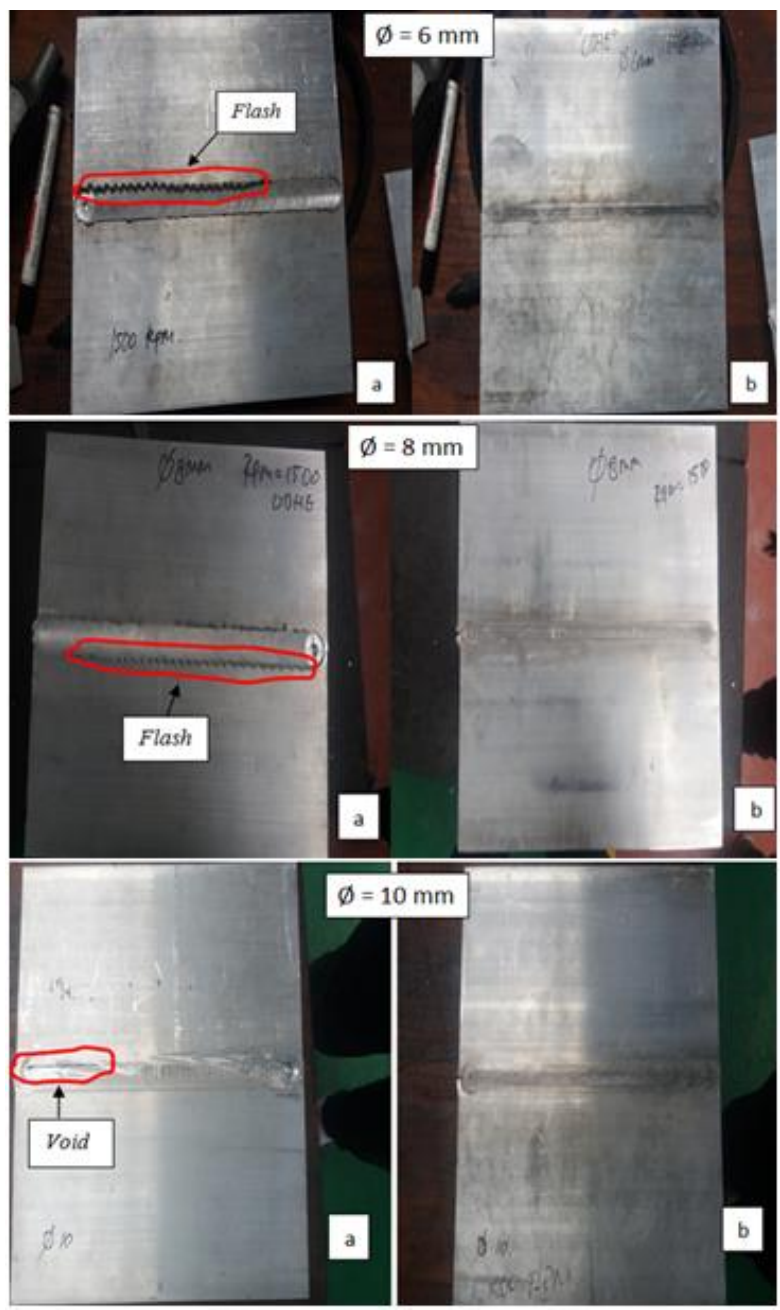

Gambar 4. Hasil Proses FSW Secara Visual

\subsection{Analisis Hasil Pemeriksaan Ultrasonik}

Hasil uji ultrasonik spesimen Aluminium 6061-T6 seperti pada Gambar 5 dengan penggunaan diameter pin $6 \mathrm{~mm}$ dan $8 \mathrm{~mm}$ pada proses FSW menunjukkan bahwa tampilan pulsa yang sama pada layar monitor antara initial pulse dan backwall pulse, yaitu signal pulsa yang selalu muncul pada saat awal tampilan pengukuran terbaca dimonitor dan juga signal yang menyatakan ketebalan bahan uji. Penggunaan diameter pin $10 \mathrm{~mm}$ pada proses FSW aluminium 6061 menunjukkan tampilan defect pulse. Hal ini ditandai dengan adanya signal pada layar monitor saat nilai reject pada alat Ultrasonic Test telah dinaikan. Pada pengujian ultrasonik dapat diketahui bahwa spesimen aluminium 6061-T6 menggunakan pin berdiameter $10 \mathrm{~mm}$ terdapat cacat di bagian dalam hasil lasan. Hasil uji ultrasonik ini menegaskan indikasi cacat void pada pemeriksaan visual untuk spesimen dengan iameter pin $10 \mathrm{~mm}$. Menurut AWS D17.3[16] cacat void yang muncul tidak bisa diterima. 

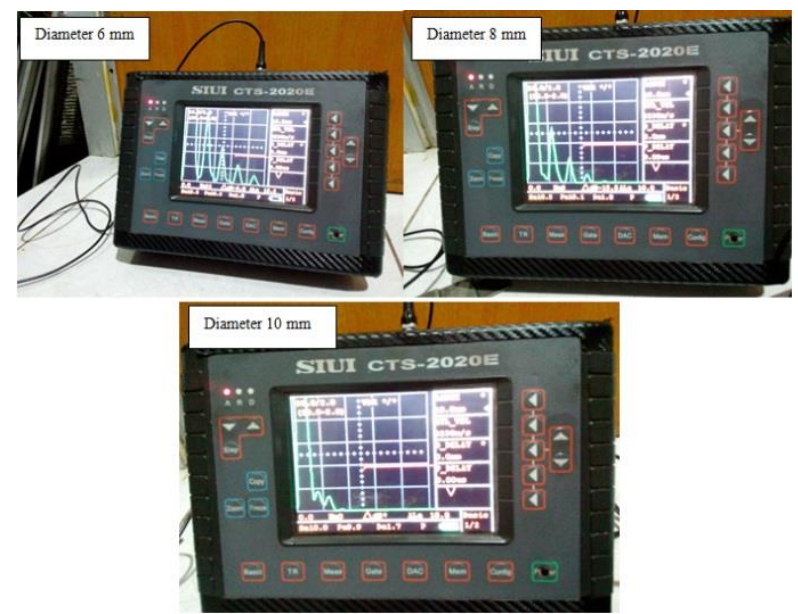

Gambar 5. Hasil Pengujian Radiografi

\subsection{Analisis Cacat dan Struktur Makro}

Setelah dilakukan pengujian tarik dilanjutkan dengan pengujian metalografi yaitu untuk melihat struktur makro. Gambar 6 merupakan hasil pengujian metalografi makro spesimen 1 dengan pin berdiameter $6 \mathrm{~mm}$ tidak terdapat adanya cacat yang berada pada daerah dekat dengan root maupun face. Metalografi makro spesimen 2 dengan pin berdiameter $8 \mathrm{~mm}$ tidak terdapat adanya cacat yang berada pada daerah dekat dengan root maupun face. sedangkan metalografi makro spesimen 3 dengan pin berdiameter $10 \mathrm{~mm}$, terdapat adanya cacat yang berada pada daerah dekat dengan face berupa void kecil berukuran 3,7 $\mathrm{mm} \times 3,2 \mathrm{~mm}$. Void yang muncul diakibatkan oleh panas yang tidak mencukupi untuk melunakkan material pada saat proses sehingga terbentuklah rongga pada daerah las sesuai dengan penelitian yang dihasilkan Podrzaj dkk [19].

Hasil uji makro ini memperjelas hasil uji ultrasonik bahwa spesimen dengan pin berdiameter $10 \mathrm{~mm}$ tidak memenuhi persyaratan untuk dilakukan pengujian selanjutnya.
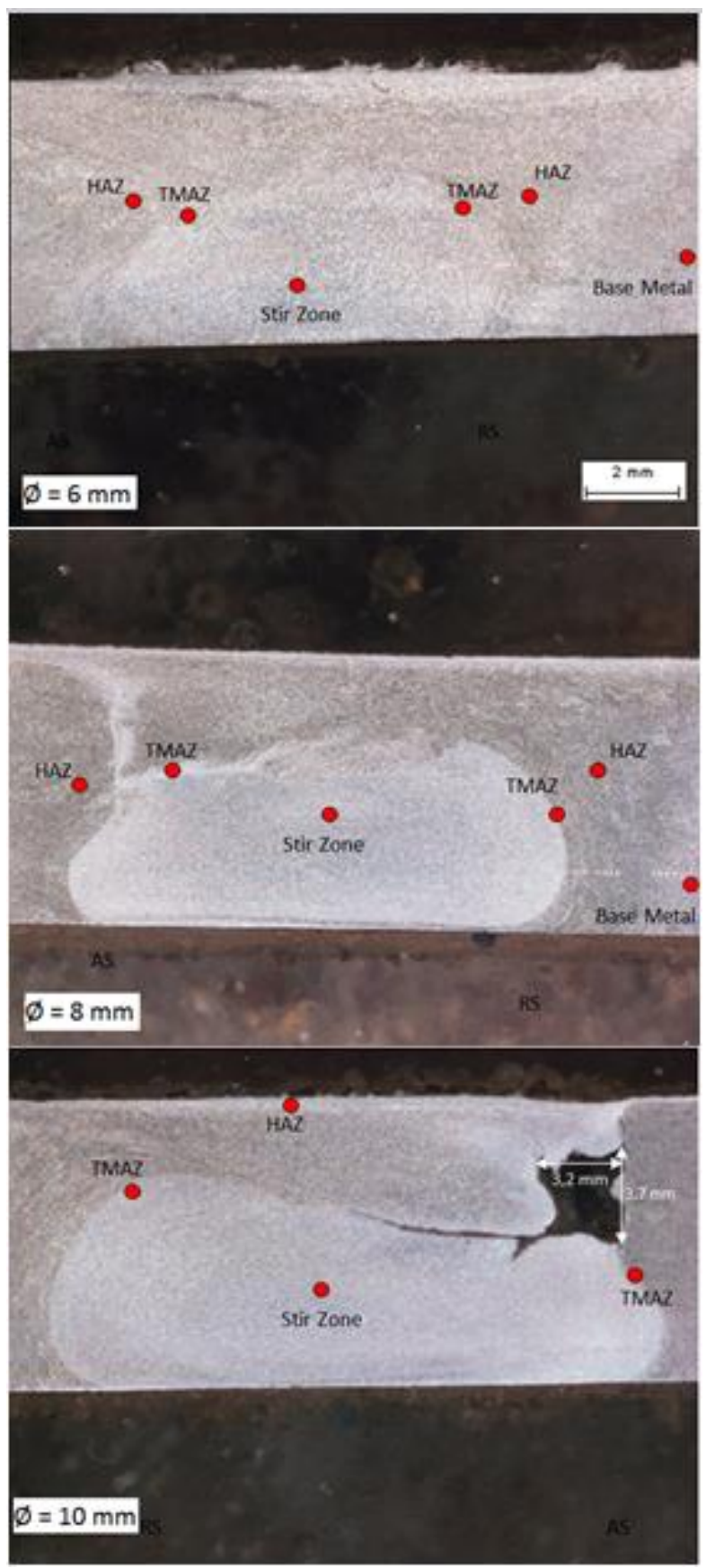

Gambar 6. Hasil uji makro

Gambar 7 menunjukan perbandingan besar daerah lasan berdasarkan perbedaan besar diameter pin pada tool, dimana semakin besar diameter pin maka akan semakin besar pula daerah lasan. Penelitian ini juga menujukkan struktur makro akibat pengadukan logam yang berbentuk onion ring seperti pada penelitian R. Chandran [20]. Semakin besar diameter pin pada tool maka daerah lasan akan semakin besar. 


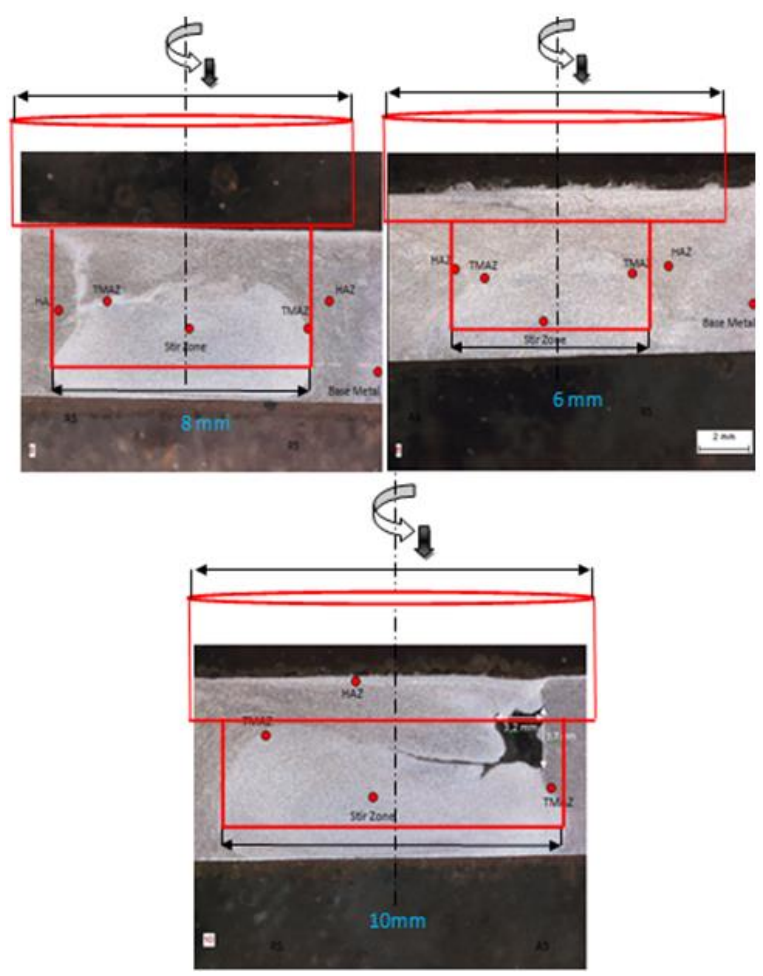

Gambar 7. Perbandingan besar daerah lasan

\subsection{Analisis Hasil Pengujian Tarik}

Hasil uji tarik yang dilakukan terhadap logam induk dan spesimen FSW aluminium 6061-T6 ditunjukkan oleh Gambar 8. Logam induk atau base metal mempunyai kuat tarik sekitar 275 $\mathrm{MPa}$, sedangkan untuk spesimen menggunakan diameter pin $6 \mathrm{~mm}$ memiliki kuat tarik berkisar $144 \mathrm{MPa}$, lebih besar dibandingkan spesimen yang menggunakan diameter pin $8 \mathrm{~mm}$ yaitu sekitar $141 \mathrm{MPa}$.

Penggunaan tool dengan diameter pin $6 \mathrm{~mm}$ menghasilkan sambungan yang lebih baik karena panas yang dihasilkan oleh putaran tool mampu melunakkan, mengaduk dan mengisi ruang kosong dengan baik ketika tool bergerak translasi daripada penggunaan pin diameter $8 \mathrm{~mm}$.

Kuat tarik spesimen uji lebih rendah dibandingkan dengan kuat tarik logam induk karena adanya sifat softening dari aluminium ketika telah mengalami pemanasan[21]. Sedangkan spesimen menggunakan diameter pin $10 \mathrm{~mm}$ tidak diuji tarik karena spesimen tidak lolos secara visual dan uji ultrasonik sesuai standar AWS D17.3.

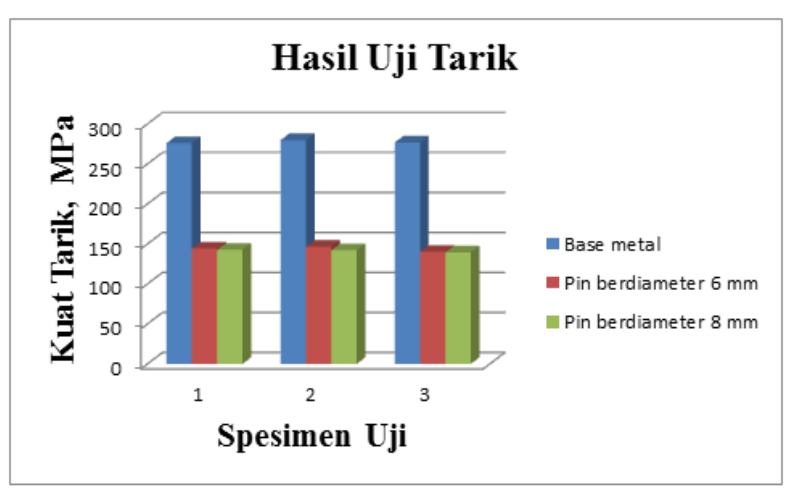

Gambar 8. Hasil uji tarik

\subsection{Analisis Hasil Uji Struktur Mikro}

Setelah dilakukan pengujian tarik dilanjutkan dengan pengujian metalografi yaitu untuk melihat struktur makro dan stuktur mikro tiap spesimen. Pada pengujian stuktur mikro terlihat adanya daerah weld metal, TMAZ, HAZ, dan base metal seperti yang terlihat pada gambar 9. Weld metal adalah daerah hasil dari proses pengelasan friction stir welding yang mengalami deformasi plastis dan pemanasan selama proses FSW sehingga mengalami rekrisktalisasi sehingga menghasilkan butiran halus di daerah pengadukan, TMAZ (thermo mechanically affected zone) adalah transisi antara logam induk dan daerah las yang mengalami deformasi struktur tetapi tidak terjadi rekristalisasi, HAZ (heat affected zone) adalah daerah yang mengalami siklus termal tetapi tidak mengalami deformasi plastis, karena temperatur pemanasannya rendah[22]. Pada pengujian struktur mikro juga terlihat adanya perbedaan antara daerah weld, TMAZ, HAZ dan base metal seperti penelitian yang telah dilakukan oleh Indra Putra Almanar.

Pada daerah weld/stir zone terlihat butir halus dan equiaxed, hal ini dikarenakan terjadinya tegangan dan temperatur tinggi yang menyebabkan material mengalami rekristalisasi. Pada daerah TMAZ tegangan dan temperatur lebih rendah dibanding stir zone sehingga efek pengelasan terhadap mikrostuktur lebih kecil. Pada daerah HAZ bentuk butir non equiaxed dan berwarna gelap dikarenakan daerah HAZ dipengaruhi oleh panas akibat proses pengelasan meskipun tidak terdeformasi plastis[14]. 


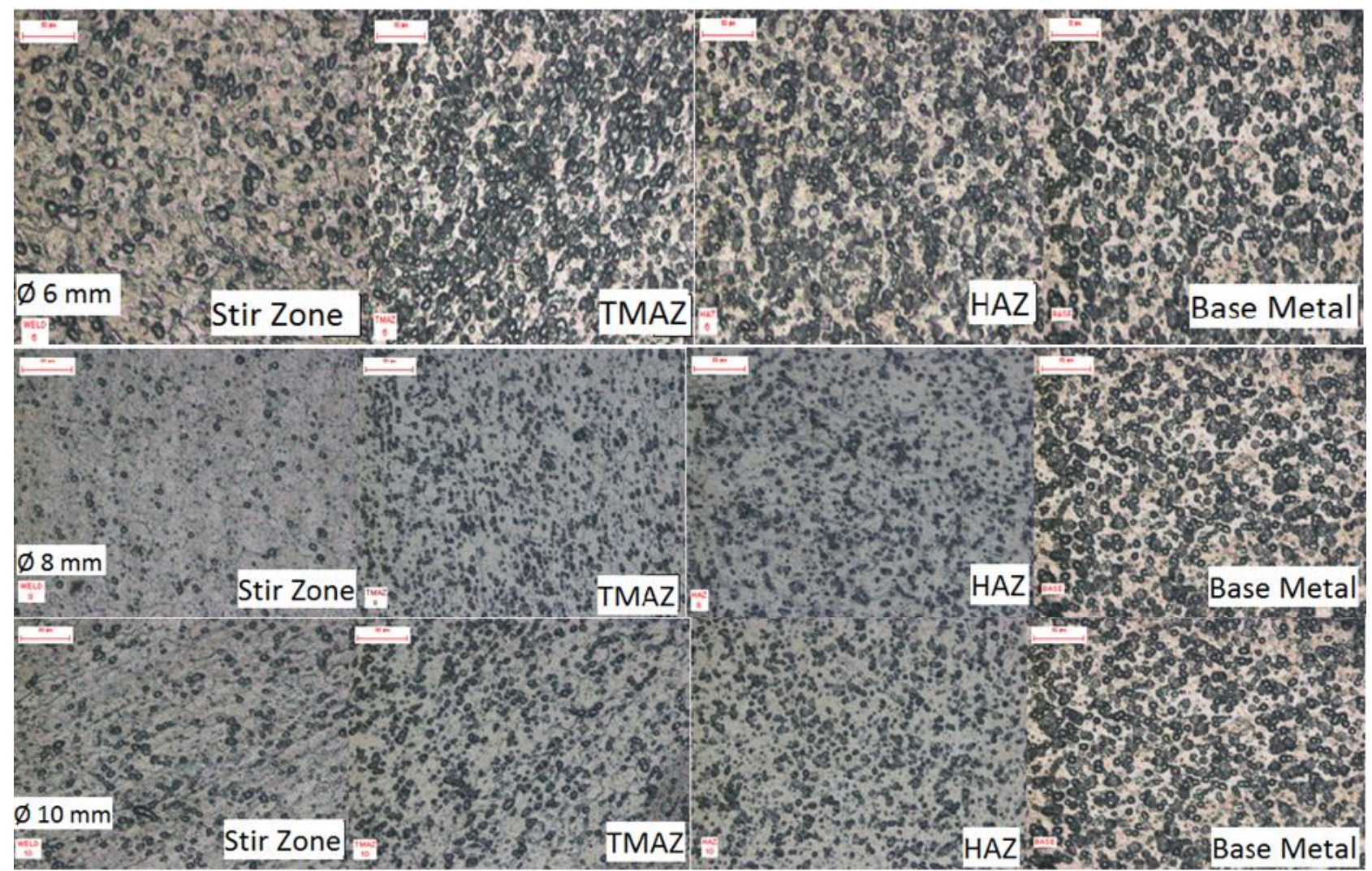

Gambar 9. Hasil struktur mikro

\subsection{Analisis Hasil Pengujian Kekerasan}

Pengujian selanjutnya adalah uji kekerasan dan hanya dilakukan pada spesimen 1 dan 2 dikarenakan spesimen 3 tidak lolos uji NDT. Merujuk pada Gambar 10 pada daerah hasil lasan baik didaerah HAZ, TMAZ ataupun weld nugget spesimen 1 dengan diameter pin $6 \mathrm{~mm}$ memiliki harga kekerasan lebih tinggi dibanding spesimen 2 . Daerah weld nugget memiliki harga kekerasan tertinggi dibanding daerah lainnya yaitu sekitar 70,27 HVN dan daerah yang memiliki harga kekerasan terendah berada pada daerah HAZ hal ini dikarenakan daerah HAZ mengalami siklus pemanasan sehingga sifat mekanik dan mikro struktur nya banyak berubah meskipun begitu daerah ini tidak mengalami deformasi plastis sehingga nilai kekerasannya menurun. 


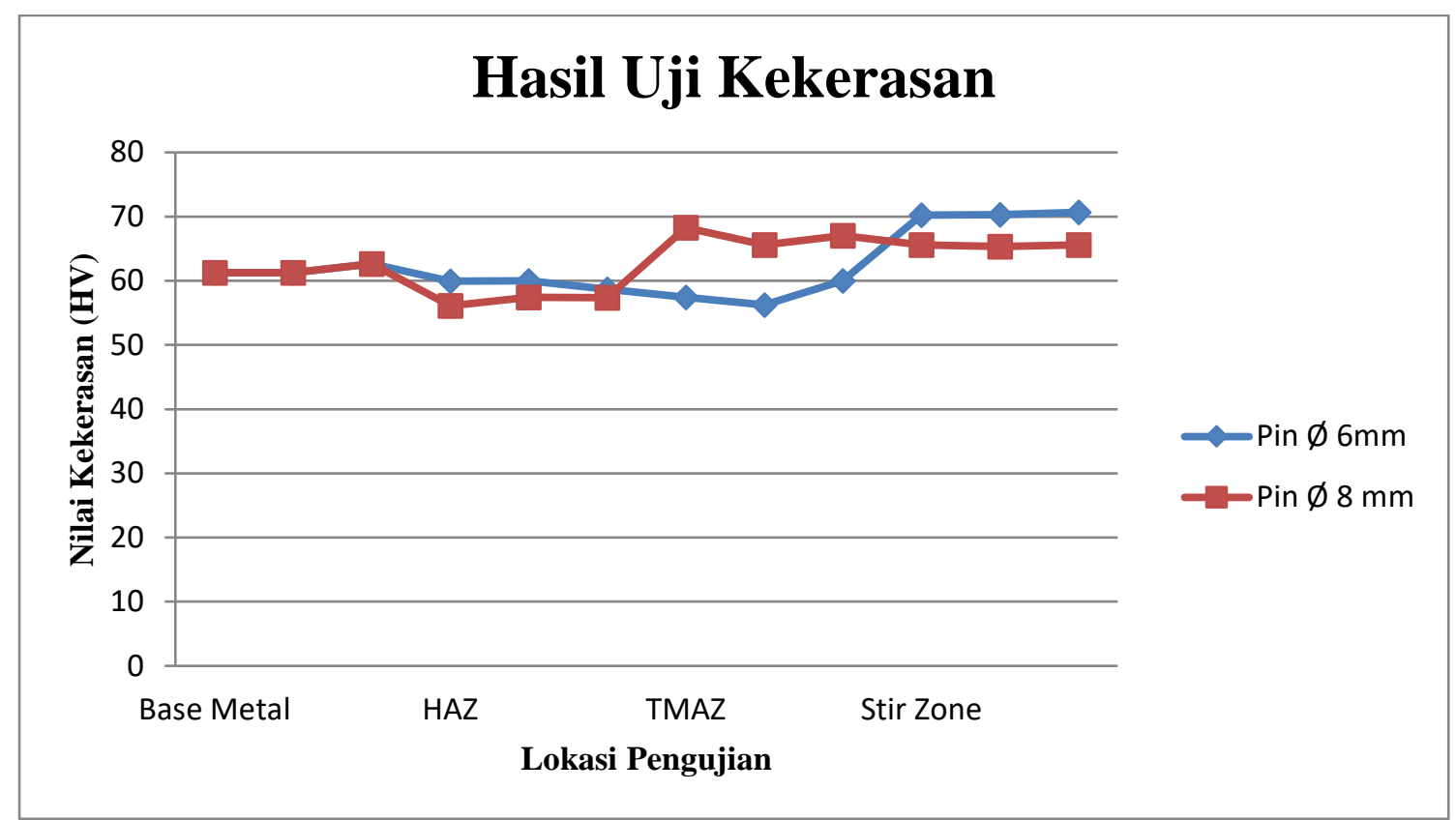

Gambar 10. Distribusi kekerasan hasil lasan

\section{KESIMPULAN}

Proses FSW aluminium 6061-T6 dengan parameter kecepatan putar 1500 rpm, kecepatan pengelasan $29 \mathrm{~mm} / \mathrm{min}$ dan sudut kemiringan tool $0^{\circ}$ telah dilakukan dengan baik. Proses FSW aluminium 6061-T6 menggunakan tool berbentuk counter clockwise threaded cylinder dengan diameter pin $6 \mathrm{~mm}$ memberikan hasil sambungan yang lebih baik secara visual, uji ultrasonik dan sifat mekanik dibandingkan dengan penggunaan diameter pin $8 \mathrm{~mm}$ yang ditunjukkan dengan kuat tarik $145 \mathrm{MPa}$ dan kekerasan $70 \mathrm{HV}$. Sedangkan proses FSW spesimen menggunakan pin diameter $10 \mathrm{~mm}$ terdapat void pada hasil sambungan. Penggunaan tool dengan dimensi pin yang tepat pada proses FSW akan memberikan hasil las dengan sifat mekanik dan struktur mikro yang baik dan optimum.

\section{UCAPAN TERIMA KASIH}

Penulis mengucapkan terima kasih yang sebesar-besarnya kepada Bapak Dr. Ing Ir. Supono Adi Dwiwanto, Staf Seksi Pemesinan dan Pengelasan BBLM yang menyediakan waktu dan fasilitas untuk penelitian ini.

\section{DAFTAR PUSTAKA}

[1] A. P. Dewanto, W. Amirudin, and H. Yudo, "Analisa Kekuatan Mekanik Sambungan Las Metode MIG( Metal Inert Gas) Dan Metode FSW( Friction Stir Welding) 800 Rpm Pada Alumunium Tipe 5083," vol. 4, no. 3, pp. 613-621.

[2] Linda Andewi, "Pengaruh Variasi Arus Pada
Hasil Pengelasan TIG ( Tungsten Inert Gas ) Terhadap Sifat Fisis Dan Mekanis Pada Alumunium 6061," Tugas Akhir Sarjana, Univ. Negeri Semarang, 2016.

[3] I. R. M, M. R. N, and A. C. S. Kumar, "A Study Of Process Parameters Of Friction Stir Welded Aa 6061 Aluminum Alloy In O And T6 Conditions," vol. 6, no. 2, pp. 61-66, 2011.

[4] U. Indonesia et al., "Universitas indonesia pengaruh perubahan parameter pemesinan terhadap sifat mekanik material ac4ch pada proses," 2011.

[5] P. Prakash, S. K. Jha, and S. P. Lal, "A Study Of Process Parameters Of Friction Stir Welded Aa 6061 Aluminum Alloy," vol. 2, no. 6, pp. 2304-2309, 2013.

[6] R. S. Thube, "Effect of Tool Pin Profile and Welding Parameters on Friction Stir Processing Zone, Tensile Properties and Micro-hardness of AA5083 Joints Produced by Friction Stir Welding," Int. J. Eng. Adv. Technol., vol. 3, no. 5, pp. 35-40, 2014.

[7] P. Manikkavasagan, G. Rajamurugan, K. Satheesh, and D. Yuvaraj, "Experimental study on the Effect of tool pin profile on aluminium AA6063 Friction Stir Welded butt joint," pp. 302-305, 2015.

[8] J. Permana et al., "Analisa Perbandingan Kekuatan Sambungan Las Material Aluminium 5083 Terhadap Pengelasan Friction Stir Welding 1000 Rpm Dengan Metal Inert Gas," J. Tek. Perkapalan, vol. 4, no. 3, pp. 705-712, 2016.

[9] I. Helmi and T. Tamizi, "Pengaruh Bentuk Pin Terhadap Sifat Mekanik Aluminium 
5083 - H112 Hasil Proses Friction Stir Welding," J. Ris. Teknol. Ind., vol. 11, no. 1, pp. 31-42, 2017.

[10] P. Biswas and N. R. Mandal, "Effect of Tool Shoulder and Pin Probe Profiles on Friction Stirred Aluminum Welds - a Comparative Study," J. Mar. Sci. Appl., no. June, 2012.

[11] R. Ashok and M. R. Thansekhar, "Effects of tool pin profile and tool shoulder diameter on the tensile behaviour of friction stir welded joints of aluminium alloys," vol. 985, pp. 586-591, 2014.

[12] A. M. Takhakh, S. Algodi, and M. Alkhateeb, "Effect Of Tool Shoulder Diameter On The Mechanical Properties Of 1200 Aluminum Friction Stir Spot Welding," no. January, 2011.

[13] N. Gharaibeh, J. A. Al-jarrah, and S. A. Sawalha, "Effect of Pin Profile on Mechanical Properties of 6061 Al Alloy Welded Joints Prepared by Friction Stir Welding," vol. 6, no. 3, pp. 39-42, 2016.

[14] I. P. Almanar, M. H. Hanapi, A. A. Seman, and Z. Hussain, "Friction Stir Welding of 6061-T6 Aluminum Alloy," Adv. Mater. Res., vol. 501, pp. 145-149, 2012.

[15] S. M. Bayazid, H. Farhangi, and A. Ghahramani, "Effect of Pin Profile on Defects of Friction Stir Welded 7075 Aluminum Alloy," Procedia Mater. Sci., vol. 11, pp. 12-16, 2015.

[16] “AWS_D17.3-D17.3M-1.” 2010.

[17] A. J. Smith, "Defects in Friction Stir Welding of Steel," Metallogr. Microstruct. Anal., vol. $1,2018$.

[18] P. Podržaj, B. Jerman, and D. Klobčar, "Welding defects at friction stir welding," Metalurgija, vol. 54, no. 2, pp. 387-389, 2015.

[19] P. Podržaj, B. Jerman, and D. Klobčar, "Welding defects at friction stir welding," Metalurgija, vol. 54, no. 2, pp. 387-389, 2015.

[20] R. Chandran and V. Kumar Senthil Santhanam, "Submerged Friction Stir Welding of 6061-T6 Aluminium Alloy under Different Water Heads," vol. 21, no. 6, 2018.

[21] W. Woo and H. Choo, "Softening behaviour of friction stir welded Al 6061-T6 and $\mathrm{Mg}$ AZ31B alloys," no. April 2011, 2014.

[22] Tarmizi and B. Prayoga, "Analisa Sifat Mekanik dan Struktur Mikro pada Proses Friction Stir Welding Alumunium 5052," $J$. Ris. Teknol. Ind., vol. 02, no. 02, pp. 105118, 2016. 